\title{
The network effect and rock lyric translation. The case of Romanian radio producers and musicians during communism
}

Raluca Tanasescu*

\begin{abstract}
Introduction
Interestingly enough, most academic essays about Romanian cultural life during the Communist regime, alongside those about the post-Communist period, paint a much gloomier picture than one would like to see. For instance, A Reader in International Media Piracy (2015) features an essay on subtitle translation into Romanian, whose introduction thrillerizes the way in which foreign movies used to reach the local audiences:
\end{abstract}

Friday nights in Romania under the Communist regime [...], friends and fami-
ly would gather in front of their television sets trying to guess what they were
actually watching. Telephone calls would be made, film reference and theory
books consulted. Such detective skills were required due to the government's
censorship tactics which included screening foreign films (both on television
and in cinemas) with their titles altered beyond recognition, credit sequences
removed, entire scenes eliminated and dialogue ideologically cleansed
through the subtitling process. (Dwyer and Uricariu 2015, p. 207)

While it is certainly true that state media was heavily controlled by the censors, the account is exaggerated and obviously employs a scenario that would dignify even a Hollywood blockbuster. However controlled and

${ }^{*}$ University of Groningen. 
slashed subtitling was, there was still a great amount of exposure of the audiences to the realities of foreign life, especially American life, which was of the utmost interest to them. One of the most familiar slogans during and after World War II until well after the Cold War and during the transition years to the democracy that followed was Vin americanii! (The Americans are coming!), an expression of Romania's deepest desire to be rescued from the Soviet burden. Specters of America were made available via other media channels (Luca 2013), such as radio shows, or via a parallel system of illegal video cassettes with Hollywood movies of all stripes, including pornographic productions. Such cassettes were readily available and many families owned a videorecorder to play them. The practice continued and intensified after the fall of the regime, then subsided once the Romanian state television and the newfangled private TV channels started to air such productions themselves a few years after the revolution.

Similarly, specters of America were often made available through rock and roll music broadcasting. If Romanian post-communism has known a strong movement of self-Americanization -“a voluntary appropriation of all things American, rather than an effect of the much cited U.S. cultural imperialism." (Luca ibid., p. 90) - the years under communism were marked by an Americanization 'on the stealth,' through escapism into a music and a literature that did not comply with the party's guidelines. However, this Americanization did not take place necessarily as a result of Romanians' interest in the formerly dubbed 'decadent West,' but, as Pop shrewdly notes, as a consequence of what was an easement of the Stalinist grip on society from 1965 to 1971, commonly referred to as 'The Thaw.' (2016, p. 54). As a result, rock and folk music, perceived as critical of capitalist societies, was among the genres that Communist cultural officialdom tried to accommodate. This relative openness towards the West favored the appearance of a local rock culture disillusioned with the local practices and ideology of local leaders. In a scholarly article dedicated to the alternative culture of the 1960s and 1970s, Madigan Fichter remarks that the "Romanian variant of the hippie movement was more 
discreet and less flamboyant than its Western counterpart, but still incorporated eccentric dress and a love of rock and beat music with a desire to escape the cultural and political rigidity of socialist Romania." (2011, p. 570) She also notes that listening to rock music was not necessarily associated to hippiedom and that two staples of this counterculture activity were the purchase of blackmarket rock'n'roll records and listening 'obsessively' to radio shows such as Metronom, by Cornel Chiriac. Rock'n'roll was the music that helped young people create a private space away from the collectivized, socialist way of life, as well as entertain a myth of Europe and the United States and present forms of culture that originated within these spaces. Most importantly, it was an informal network phenomenon that propagated fast and was entertained by the one-way network effect of forbidden radio broadcasting.

One important media outlet that contributed to this phenomenon was Radio Europa Liberă (Radio Free Europe), which had a lasting influence on the "unknowing" Romanians: "The average Romanian is not allowed access to information, to experience. In constructing the images of the West, he cannot use personal experience or provable knowledge, because he doesn't have any." (Biro and Rostas 2001, p. 94) Secretly listening to such radio stations was one of the favorite past times of many young Romanians and music programs were extremely popular. Although heavily controlled by the Securitate, rock programmes were recorded on tape and then circulated within informal networks, between friends, to the extent to which they created social attitudes (Pop 2016, p. 56). Massively targeted by censorship, playlists of local radios were carefully combed and only classical love songs or folk music were accepted (ibid.). However, many resourceful radio people would find ways to include otherwise banned rock songs in their programs and would cater to those rock fans with a certain limited access to Western cultural products. Rock music did not gain currency only because of the thrill of the banned, but mostly because of its socially-engaged content, because of the "smuggling of ideas and beliefs into the Soviet world" (McMichael 2008, p. 205) of which Romania was part at the time, as well as because of young people's interest in the Western forms of ex- 
pression (Fichter 2011); thus radio programmers would also translate the lyrics (Ionescu 2005, Vasiliu 2005), making sure the message would reach those listeners who didn't have any knowledge of English. The tightly knit rock network vibrated at the lyrics of the Beatles, Led Zeppelin, Bob Dylan, The Doors, and other such bands and had private revelations about what the West looked like: the West looked like those bands and sounded like their hard-won music.

Both before and after 1989 rock lyrics were the ones typically associated with translation projects ${ }^{1}$ - be they personal or institutional. In this essay I analyze those projects stemming out of radio programs and those grounded in individual preferences and initiative. This node is formed of radio people that have been considered by the Romanian rock community as trailblazers (Cornel Chiriac and Florian Pittiș), as well as of musicians (Alexandru Andrieș). For lack of consistent academic sources ${ }^{2}$ related to three of these music specialists, this research is based on online audio and video recordings, interviews, and heartfelt accounts by people who knew them personally or professionally.

\section{Rock Lyrics as Subversion: Jesus Christ Superstar}

Postcommunist rock lyric translation needs to be analyzed in close relationship with the same phenomenon before 1989 because it owes a great deal to several Romanian radio celebrities and musicians, who promoted jazz and rock music during the Communist regime, sometimes at the expense of their own lives. At the onset of the liberalization period, in 1964, the music scene in Romania started to become familiar with the music of great American jazzmen, like Louis Armstrong, or American and English rock musicians and bands, such as Bob Dylan, the Beatles, Jimi Hendrix, and many others. That came after almost twenty years in which jazz had been considered the art of the rotten West and forbidden by the propaganda. The jazz that still existed in Romania during

\footnotetext{
${ }^{1}$ Since there is no official statistics related to lyrics translation, I rely completely on factual data identified during the present research.

2 The only scholarly article in English that mentions Florian Pittiș is related to his activity as an actor: Berlogea, Ileana. 1979. Shakespeare in Romania. In Shakespeare Quarterly, 30 (2): 281-285. Andrieș is not referenced in any scholarly work.
} 
those years was a superficial version called muzică de estradă (a term ${ }^{3}$ imposed by the Composers' Union in Moscow), very similar to swing-the only kind that was allowed on the national radio and television. The lenient 1964 brought a change that was expected by many young people: jazz was called by its rightful name on national television, real jazz began to be played in fashionable clubs in the cities, international music festivals were set up, concerts were organized, and albums released.

In this atmosphere, a radio show successfully counted for a sort of sound utopia for many young people: "Metronom," by Cornel Chiriac, a selftaught jazz and rock specialist, arguably the most famous Romanian radio DJ of all times. Chiriac presented his audience with a special kind of show, in which not only did he play good music, otherwise inaccessible to most, but he also commented "on political issues and promoted the freedom of expression against the regime," (Pop 2016: 57) as well as on the lyrics; he would also translate them for those listeners that could not comprehend them. Translation took an important part of his time:

An incredible work capacity, musical knowledge, an infallible taste, a spiritual openness towards any viable experiment, knowledge of subtleties in literary English from which he translated hundreds of rock and progressive rock lyrics, a mission to promote culture on the radio that he shouldered not with selfimportance, but naturally, with a passion and communicative warmth that made him extremely popular both in Romania and also in many European countries. Young Italians, Dutch, Swedish, Russians, Bulgarians used to listen to his shows although they didn't understand what he was saying. His intonation, impeccable pronunciations of names, his natural speech claimed everyone's hearts. In the "Prometeus" Club I learned that Metronom was listened to even in Irkutsk, Siberia. (Vasiliu ibid.: web, emphasis mine)

His program started to broadcast in Romania in 1967, but ended in 1968, when it was forbidden because Chiriac dared to include a Beatles song

\footnotetext{
${ }^{3}$ A musical genre similar to the vaudeville-characterized by simplicity and containing short, entertaining vocal and instrumental songs that audiences could dance on.
} 
titled "Back in the USSR" on his playlist. Following the ban on his show, the DJ defected to Austria and then Germany, where he was discovered by Noel Bernard, Director of Radio Free Europe. Thus Chiriac was given the opportunity to offer "his contagious lesson in liberty" (Tismăneanu 2012: web) again: "Metronom" was broadcast anew between 1969 and 1975, when he was stabbed in a parking lot in Munich, an assassination possibly commissioned by the Romanian Securitate (Ionescu 2005: 25; Tismăneanu ibid.).

Chiriac was the first to put together a professional study on the roots and history of jazz music, a 20-page monograph published by Secolul XX in 1966, the one who signed the foreword to the Romanian translation of My Life in New Orleans, by Louis Armstrong, and the one who wrote the introductory blurbs for several jazz LPs released by Electrecord, the national label at the time. Besides thoroughly transcribing all the foreign sources on jazz and rock he managed to get his hands on, Chiriac would sometimes translate the lyrics of the songs he played on the radio, especially the ones bearing political messages - his way of opposing the oppressive political regime in Romania and of educating young people on democracy some twenty-five years before the Romanians came to know it:

\footnotetext{
To him, the social phenomenon, the revolt and the discontent that emanated from these songs and that were often mirrored by their lyrics were at least as important as the music. As you well know, Cornel was an encyclopedia of modern popular music, one of the best specialists. A man that understood it to perfection because he understood its roots, he knew where it came from, and he empathised with its thirst for freedom and peace, its aversion to war and brutality. (Bernard, quoted in Tismaneanu 2012)
}

During a visit he made to Chiriac's only living relative, Cornel Chiriac Jr., his nephew, reputed rock specialist and radio programmer Doru Ionescu discovered the translation into Romanian of Jesus Christ Superstar:

At Junior's I came across the translation of the Jesus Christ Superstar rock opera (a sensational one, in my opinion!), brought from his house in Munich... I hope 
that one day I'll be able to support its staging. That would be something for Cornel's memory, how he remained in the hearts of millions of Romanians (and this is not an exaggeration!) who used to listen to his music shows more than the political talk-shows by his colleagues at Radio Free Europe... (2001, web)

Intrigued by Ionescu's finding, I searched the internet for a recording of the radio show in which Chiriac presented the Jesus Christ Superstar LP. Luckily, it is one of the very few recordings that are available today: the radio programmer presented the double LP during four 45-minute shows scheduled immediately after the release of the album, in 1970. However, only three of them were available on Youtube, though enough to offer a clear image of the way in which Chiriac structured his show and presented the lyrics. The first part starts with the detailed presentation of the authors of the rock opera, followed by a presentation of the characters and the singers that interpret those characters. He would then start presenting the songs in the order in which they appeared on the LP, each song preceded by his own translation. Chiriac is very aware of the translation process and explains that he found it to be "an interesting, but also tedious work," (min. 20-21, Part $1^{4}$ ) as he tried to offer a rhymed version. He explains that he uses simple language, similar to the language in the original, but with "a light archaic nuance." (ibid.)

I listened to all three radio shows and transcribed all his translations and since I did not have the written version that Ionescu discovered among Chiriac's personal things and there is not any other written copy, I relied completely on the oral version, therefore the formatting is mine and is also based on the formatting of the originals. Chiriac's translation shows his deep engagement with the message of the opera, which he renders faithfully in a compelling fashion; his commentaries demonstrate a thorough understanding of the cultural references and significance: "It is obvious that Jesus Christ Superstar is an attempt to make a comparison between Jesus's passions and the fate of

\footnotetext{
${ }^{4}$ Youtube source: http://bit.ly/ChiriacJCS
} 
the modern musician. Does he want himself to be-or do others want him to be-a mentor, a spiritual Messiah of the young generation, or rather a social, political one?" he asks apparently rhetorically during the second part of the show; ${ }^{5}$ he also provides erudite explanations on various aspects such as the etymology of certain words and names (e.g., the origin of the name Judas the Iscariote, which derives from the Latin sicarius, an assassin, a murderer, etc.), as well as on the historical background of the accounts.

Chiriac translates the title as "Iisus Cristos idol," using idol as the equivalent for "superstar," although the English term would be perfectly acceptable in today's language. Even if his choice may sound like an infringement of the second commandment that urges believers to "not make unto thee any graven image, or any likeness of any thing that is in heaven above, or that is in the earth beneath, or that is in the water under the earth" (Exodus: 20, Bible, King James version) - or, the more modern version "You shall not make idols." - that is rather unlikely, as he sounds in fact quite attached to the story behind the opera. His word choice relates more consistently to pop culture and to the condition of modern musicians: in "This Jesus Must Die", he explains his translation of "Jesus Christ-mania" as Iisus Cristos mania (a calque after the English phrase) through an obvious hint to "Beatle-mania" and to Lennon's remark that the Beatles were more popular than Jesus; he relates people's request for a written proof from Jesus to autographs offered to fans; and uses primul în clasament (first on top) for "he's top of the poll."

Chiriac's attention to form, especially to rhyme-that he wants to preserve at all costs - and his lack of formal training in versification lead to a series of facile rhymes or awkward phrasings. However, his translation is exquisite given the context: a radio show of the 1970s, whose presenter had only a bachelor's degree in English and was mostly self-educated, and could not take advantage of today's affordances of the internet. He produces an oral version in Romanian that can be easily understood and memorized. Although he

\footnotetext{
${ }^{5}$ As Chiriac explains (part 2, minute 25-26).
} 
might not have been interested in how his renditions would work as lyrics, his versions sound remarkably convincing in oral performance. Here is for example the Romanian translation of "What's the Buzz?"

What's the Buzz?

Apostles:

What's the buzz?

Tell me what's a-happening.

Jesus:

Why should you want to know? Don't you mind about the future? Don't you try to think ahead?

Save tomorrow for tomorrow;

Think about today instead.
Part 1, minute 31:00

Ce se-aude, ce se-ntâmplă?

Translated by C. Chiriac

Apostolii:

Ce se-aude,

Ce se-ntâmplă?

Iisus:

De ce oare vreți să știți?

Viitorul - ce vă pasă?

La ce vine nu gândiți?

Lăsați mâine pentru mâine,

Voi pe astăzi chibzuiți.

\section{What is Happening?}

(Back translation)

Apostles:

What's that noise, What is happening?

Jesus:

Wondering why you'd like to know Don't you care about the future? You don't think about what's next? Leave tomorrow for tomorrow, Ponder only upon today.

His versification, lexical choices and diction bear a striking resemblance to those of famous poem "Glossă" (Gloss), ${ }^{6}$ by widely revered $19^{\text {th }}$ century early Modernist Romanian poet Mihai Eminescu, but also offer an almost literal translation of the original. The first song that he translates, "Cerul din mințile lor" (Heaven on their Minds), shows his great awareness of the different rhythms in the original: after he reads 25 lines, he stops, explains a background fact, warns the listeners that there is a change in meter in the original, provides a translation that has a different rhythm and meter, then signals when the text goes back to the initial meter and adapts his translation accordingly. When literal translation and the preservation of the rhyme are not possible concomitantly, he does not shy away from adapting his version. Perhaps the best crafted adaptation is the introduction to "The Temple", which he translates as Corul cămătarilor și al negustorilor ("The Choir of Moneylenders and Merchants"):

6 An excellent English translation by Corneliu M. Popescu is available at http://www.estcomp.ro/eminescu/gloss.html. 


\section{The Temple}

I got things you won't believe, Name your pleasure I will sell.

I can fix your wildest needs, I got heaven and I got hell.

Roll on up, for my price is down.

Come on in for the best in town.

Take your pick of the finest wine.

Lay your bets on this bird of mine.

What you see is what you get.

No one's been disappointed yet.

Don't be scared give me a try,

There is nothing you can't buy.

Name your price, I got everything.

Hurry, it's going fast.

Borrow cash on the finest terms.

Hurry now while stocks still last.

Part 2, minute 38:17

Corul cămătarilor și al negustorilor

Fă-te-ncoa, fârtate, vând la preț scăzut, Neamule, am marfă cum n-ai mai văzut. Pun pariu că vinul meu dă viață

Păsări c-ale mele nu găsești pe piață.

Spune ce dobândă și-ți dau oricât vrei

Vino, poți să cumperi tot pe banii mei.

Pe lungă scadență dau cu-mprumutare

Bani peșin, la bursă cursul e-n urcare.
Back translation

Choir of Moneylenders and Merchants

Come on over, brother, everything's on sale, Folks, got stuff you've never seen before, Bet my wine is life-giving, There is no fowl like mine.

Just name your interest and I'll pay your price, Come on over, you can get it and I'll pay.

I lend money to you even long-term,

Cash is on the spot, the rate is going up.

He provides a shorter version, only 8 lines instead of 16, in which he takes the most important cues from the original (marked in bold) and recreates the poem, offering two vivid, springy, and funny Balkan style quatrains. Interestingly enough, there is no evidence of Chiriac's being aware of poets like John Cage, Jerome Rothenberg, or Charles Bernstein and their "writing 
through" techniques, ${ }^{7}$ and therefore most likely such uncommon approaches to translation and the resulting brilliant versions emerged from his heartfelt dedication, playful ingenuity, and resourceful creativity.

Chiriac's example does not typify subversive radio activities under communist rule, but is a niche mode of engagement with the audiences through rock lyrics during a time when literature and music were the only refuge for many young people. Translation of rock lyrics thus became, just as pirated subtitles (Dwyer and Uricariu ibid., p. 221), a by-product of censorship practices and illustrated the primacy of the agent, network, and the media, and the importance of the message, rather than of its originality or accuracy. In a country where in 1991 electric guitars were still 'scarce,' (Negus 1992, p. 108) rock-mania provided a necessary escapism, while translating lyrics into Romanian was perhaps a result of the introversion and insularity of the Romanian hippie movement (Fichter 2011, p. 578), in that they might have been the expression of a self-referential counterculture rather than arduous political activism. Also, while the existing literature generally links folklore-infused Romanian rock to a nationalism that was accepted by the Communist regime (Pop 2016, Dobrescu 2011), one also needs to acknowledge the fact that it may have been a response to Mircea Eliade's impact as a historian of religions $\left(\right.$ Oișteanu 2006) ${ }^{8}$ and a symbol of the alternative ways of approaching Romanian culture. I would argue here that, for example, Cornel Chiriac's choice to translate Jesus Christ Superstar in its entirety may have been the result of an Eliadesque mode of perceiving and promoting music and that translation was his very personal way of understanding it. Claire Bishop rightfully notes that self-organization and personal experience were important modes of experiencing art in general under socialism: "For artists living under communism, par-

\footnotetext{
${ }^{7}$ For Jerome Rothenberg, for instance, translation is a form of writing through the words of others. He also uses a technique he calls 'variation', which means deriving new poems from the key-vocabulary of poems he translated (cf. Writing Through: Translations and Variations. Middletown, CT: Wesleyan University Press, 2004).

${ }^{8}$ Andrei Oișteanu also documented and explained the impact of this world-famous historian of religions on hippiedom beyond Romania, specifically in California, during the 1960s and the early 1970s.
} 
ticipation had no [...] agitationary goals. It was, rather, a means of experiencing a more authentic (because individual and self-organized) mode of collective experience than the one prescribed by the state in official parades and mass spectacles; as such, it frequently takes escapist or celebratory forms." (2012: 161) Translation becomes, through the work of radio producers like Cornel Chiriac, a celebration of rock music and of underground culture in general.

\section{Bob Dylan Translated by Musicians}

The tradition of translating rock lyrics continued after Chiriac's death with Florian Pittiș, one of Romania's most loved actors, radio presenters, and vocalists. Known as "a perpetual teenager" (Moceanu 2017, web) passionate about theatre and rock music, Pittiș never quite fell in line with the Communist Party and famously turned down even their request to have his hair cut. ${ }^{9} \mathrm{He}$ had decisively contributed to promoting artists like Bob Dylan, The Beatles, Led Zeppelin, and the Rolling Stones among Romanian youth both before and after 1989. After starting out as a successful actor in 1968 and after years of work with Bulandra Theater in Bucharest, Pittiș initiated in 1981 a series of galvanizing shows called "Poezia muzicii tinere" (The Poetry of Young Music), during which he used to present and comment on the lyrics of various foreign rock bands and artists. His rugged, yet warm and fascinating voice, not only presented the English originals, but also delivered translations of the texts that he had done himself. To Pittiș translation was a natural act, a spontaneous response to his meeting with a foreign culture, to which he added, just as naturally, a performative dimension: any text he would read was approached with the awareness of an audience. His show at the theater was banned in 1985, but was followed by "Cântece pentru mine însumi ${ }^{10}$," (Songs for Myself) which ran

\footnotetext{
${ }^{9} \mathrm{He}$ was one of the young people identified as objectors, who normally had their long hair and blue jeans scissored (Ionescu, 2005, p. 36, 50).

${ }^{10}$ A title inspired by Songs of Myself by Walt Whitman, whose poems Pittis would often recite during the show.
} 
between 1985 and 1989, and by "Cum se numeau cei patru Beatles" (written by Stephen Poljakoff under the original title of City Sugar) whose format allowed Pittiș to play a music normally banned by the censors. The kind of shows he organized at various theaters allowed him to promote this type of culture through a two-way network effect: his shows were not only meant to disseminate the desired information to a specific audience, but also to have the audience interact with the artists and make their voices known in a unique type of rhizhomatic performance.

Theater was not the only venue where Pittiș explored the advantages of the two-way network effect. After the revolution, he was the producer and presenter of two legendary radio programs, "Pittiș Show" and "Rock Panorama", which ran for years before Pittiș was appointed as a director of Radio Romania Tineret in 1999, a branch of the state-owned radio channel. Passionate about information technology, Pittis moved his show online and thus revolutionized radio broadcasting by adapting to the requirements of digital media and, more importantly, by involving-again-his abundant audience in his shows: he would maintain direct contact with his listeners via the chat room, he would broadcast live from the studio, and he would often propose the topics to be discussed in the forum section of the website. All these were the elements of a completely new work ethics in Romanian radio and made Pittiș a trailblazer of dynamic radio programming (Moceanu 2017, web).

Besides translating live the lyrics of the rock bands presented, he translated and adapted many of Bob Dylan's songs, such as "Death is Not the End" (Sfârşitul nu-i aici), "Don't Think Twice, It's All Right" (Nu-i nimic, asta e!) or "Rainy Day Women" (Toți suntem puțin luați...). In 2001, Pittiș became lead vocalist for Pasărea Colibri, one of Romania's most famous folk bands, and started to sing his own translations of Dylan's. His penchant for rock music in general was expressed repeatedly in interviews: "[...] there are people that live passionately; I love such people. They feel that in rock music one cannot lie or, at least, it's more difficult to lie than in any other genre. Rock is still very much a howl." (Stoicescu 2009, web) The obvious reference to Allen Ginsberg's famous 
poem is one of the many proofs that Pittis had a deep understanding of what the role of young generations was: he believed in the power of people to shape the world and rejected their role as mere cogs in the social and political machine. He valued the importance of free speech, of freedom in general, and of each person's ability to think for themselves-all masterfully expressed through the iconic lyrics of "Vinovații fără vină," a song he sang with his band Pasărea Colibri: "Nu contează cât de lung am părul / Important e ce și cum gândesc." (It does not matter how long my hair is, / But how and what I think do). His affinity for Bob Dylan's music should thus come as no surprise as the covers ${ }^{11}$ he played with his band are the natural extension of the ideals he shared with the legendary American artist all his life-and certainly not a faute de mieux, as musical covers are usually perceived. The interview he gave after having been appointed director of Radio Romania Tineret in 1999 spells out his vision on education through the un-mediated absorption of culture:

\begin{abstract}
I have faith in our true youth, in these children who refuse ready-made truths, who refuse to believe everything they are told at school or at home, who study because they need to study, because life will present them with hardship anyway and they will find useful for their education all those basics taught in school. Fortunately, just like it used to happen when I was young, there is still a certain 'underground' culture, that they explore by themselves, during 'school breaks'. When I was in school, I would read [Lucian] Blaga ${ }^{12}$ only because he was banned. But also because of my parents (May they rest in peace!), I would read Gazeta literară and Contemporanul. At the same time, I would listen to Elvis Presley, play football and be crazy about "Rock around the clock." [...] Such young people still exist in our country! And they are very many! With a thirst for culture, a thirst for knowing all kinds of things! So my mission is to present Romanian youth with such underground culture. (Kerim 1999, web)
\end{abstract}

\footnotetext{
11 Possibly included among the over 26,000 covers of Dylan inventoried before 2010 (Gezari and Hartman 2010, p. 152).

12 Romanian interbellum philosopher and writer who famously refused to support the Communist regime. Fired from his academic position with the university in Sibiu, he worked as a librarian and became a prolific translator.
} 
The translation of rock and folk lyrics represented both for Chiriac and for Pittis a way to fill a cultural gap, the kind that widens uncontrollably under oppressive political regimes. Besides filling this gap and importing resources, Pittiş also used translation creatively, adapting Dylan's songs to speak to young Romanians and to preserve their performativity. Just to offer an example of such adaptation, he translated "Rainy Day Women" as Toți suntem puțin luați..., which is in fact a line in the chorus: "Everybody must get stoned." $\mathrm{He}$ employs the colloquial a fi luat (to be tipsy) and reads in Romanian "We are all a bit tipsy..." (literally: "we are all a bit taken"), thus replacing stoned with "tipsy/drunk", a translation that was bound to be more relevant for his listeners, much more familiar at the time with alcohol than with any kind of illegal substances. The reference to drugs is also suppressed in the body of the text: he translates "they stone you" by te iau, which can be interpreted both as "I take you", but also as "they take you". Most importantly, his use of the verb "a lua" both for "they stone you" and "we are all tipsy" is a very creative way to avoid the reference to drugs, to use a leitmotif just as the original does, yet create two different meanings, of which one refers to alcohol, and one refers to political interference in and control over people's lives. His choice also entertains the ambiguity of the original, which plays with the religious connotations of to stone someone to death.' Furthermore, another simply genius solution for the first line of the chorus - "But I would not feel so all alone" - is the very idiomatic phrase "Dar hai să ne avem ca frați" ("But let us all get along just like brothers do"), which creates a perfect rhyme with the final line:

\section{Everybody Must Get Stoned \\ (fragment) by Bob Dylan}

Well, they'll stone you when you are all alone

They'll stone you when you are walking home

They'll stone you and then say they're all brave

They'll stone you when you're
Toți suntem puțin luați

Translated by F. Pittiş

Te iau când numai tu ți-ai mai rămas,

Te iau și-atunci când mergi și tu acas',

Te iau și-apoi îti spun că esti bărbat,

Te iau când în mormânt te-ai
We Are All Taken/Tipsy

(Back translation)

They'll take you when you have only yourself,

They'll take you when you're on your way home,

They'll take you and then they'll call you a man, 
sent down in your grave

But I would not feel so all

alone

Everybody must get stoned așezat!

Dar hai să ne avem ca frați,

Toți sîntem puțin luați!
They'll take you even from your grave!

But let us all get along just like brothers do

We're all taken/tipsy, after all.

Finally, while the original quatrain employs an irregular iambic pentameter (with a syllable elision in the fourth iamb), which becomes regular only in the final line, the Romanian version is built on a perfectly regular pentameter that helped the translator perform the song with much more ease and rhythm ${ }^{13}$.

A selection of Dylan's lyrics was translated and published in book form for the first time in 1991 by folk singer, song writer, writer, and architect Alexandru Andrieș. The collection was released on the American singer's fiftieth anniversary and is titled (Happy Birthday) Dylan. It contains twenty-five poems and a presentation by the translator himself, which includes five more translations (full texts or simply relevant fragments). Andrieș explains from the get-go that the selection was made following his own taste and preference for one poem or another, rather than on grounds of a certain literary hierarchy, and that it offers more of a personal version in Romanian rather than a translation proper. However, it is interesting to note that some of his translations are quite accurate (at the expense of the rhyme), while others run the gamut from simple elisions of less familiar references (e.g., he drops the reference to Anita Ekberg and keeps the reference to Sophia Loren and Brigitte Bardot in his translation of "I Shall Be Free") to inserting words that were not in the original or even rewriting whole lines (e.g., "It's President Kennedy calling me up" becomes Preşedintele Kennedy exagerează (President Kennedy is exaggerating), or "what do we need to make the country grow" becomes "Ca să ne crească

\footnotetext{
${ }^{13}$ A very illustrative interpretation of Dylan's “Rainy Day Women” by Florian Pittiș in Romanian - a concert organized in 1997-is available on Youtube at http://bit.ly/2kP4daq. The original can be accessed at http://bit.ly/2e7lvhp
} 
țara ca lanul de ştevie" (So that our country grows like a field of patience $\left.\operatorname{dock}^{14}\right)$.

\begin{tabular}{|c|c|}
\hline $\begin{array}{l}\text { I Shall Be Free (fragment) } \\
\text { by Bob Dylan }\end{array}$ & Translation by Alexandru Andrieș \\
\hline $\begin{array}{l}\text { Well, my telephone rang it would } \\
\text { not stop }\end{array}$ & $\begin{array}{l}\text { Telefonul sună, mă enerveaz } \breve{a}, \\
\text { Preşedintele Kennedy exagerează }\end{array}$ \\
\hline $\begin{array}{l}\text { It's President Kennedy callin' me } \\
\text { up }\end{array}$ & $\begin{array}{l}\text { Zice: prietene Bob ce crezi că ne trebuie } \\
\text { Ca să ne crească țara ca lanul de ştevie }\end{array}$ \\
\hline $\begin{array}{l}\text { He said, My friend, Bob, what do } \\
\text { we need to make the country } \\
\text { grow? }\end{array}$ & $\begin{array}{l}\text { Ii zic: prietene John mai ești acolo, alo } \\
\text { Ne trebuie Sophia Loren şi Brigitte } \\
\text { Bardot }\end{array}$ \\
\hline $\begin{array}{l}\text { I said my friend, John, Brigitte } \\
\text { Bardot }\end{array}$ & Şi creşte țara. \\
\hline $\begin{array}{l}\text { Anita Ekberg } \\
\text { Sophia Loren } \\
\text { Country'll grow }\end{array}$ & \\
\hline
\end{tabular}

\section{Shall Be Free (fragment)}

by Bob Dylan

Well, my telephone rang it would

President Kennedy callin' me

said, My friend, Bob, what do

we need to make the country

Bardot

Sophia Loren

Country'll grow
(Back translation)

The phone's ringing, getting on my nerves,

President Kennedy's exaggerating

Says: Bob, my friend, what is that we need

To make our country grow like a field of patience dock?

I tell him: John, my friend, still there?

We need Sophia Loren and Brigitte Bardot

And the country will grow.

Such inconsistencies in the manner in which he translated these lyrics stem from the personal nature of this translation initiative, as well as from the fact that some of them were performed in concert or on Andrieș's LPs: the meter is not observed where it should be, rhymes are used although they are not present in the original, meter is more regular than in the original, whole songs are adapted or even rewritten, etc. For example, on his "Alb negru" LP (1999), "Oxford Town" becomes "La noi" (In Our Neck of the Woods) in the title proposed by Andrieș, then various other Romanian toponyms across the quatrains, which are all mockingly rewritten and brimful with cultural references (e.g., Periş is a small satellite town of Bucharest and also commonly known as the first train station after the capital, here praised for having houses with roofs and no McDonald's):

\footnotetext{
${ }^{14}$ Lat. Rumex Patientia, a plant used in Eastern Europe in soup stocks, especially in spring. It is referenced here as a symbol of abundance due to its perennial nature and leafy appearance.
} 
Oxford Town

by Bob Dylan

Oxford Town, Oxford Town

Everybody's got their heads bowed down

The sun don't shine above the ground

Ain't a-goin' down to Oxford Town
La noi

Translated by A. Andries,

La Periş, la Periş,

Casele-au acoperiş,

Nici McChicken, nici

McFish,

Minunat e la Periş̧!
In Our Neck of the Woods

(back translation)

In Periş, in Periş

All houses are quite roof-

ish,

No McChicken, no McFish, It's amazing in Periş!

The translator took many liberties, but fully acknowledged them in the foreword, emphasizing his need to render Dylan into Romanian over any personal creative merits. However, I consider his version of "Rainy Day Women" to be less accomplished than the one by Pittiș, although I believe he took his inspiration from it (e.g., Andrieș uses Ți-o fac ("I'll trick you") for Pittiș's Te iau: although an interesting choice, it was much easier to achieve with an established translation in place.) Unlike Andrieș, Pittiș thrived in translation: he sounded much more natural, and the sense of appropriation felt less acute, as he would often sing the original lyrics after interpreting the cover version in Romanian, therefore the relationship between the original and the translation was maintained explicit on more than just one level. To Pittiş, translation came more fluidly, spontaneously, consistently (he even translated the name of the band Rolling Stones as "Vântură lume" (The Wanderers, quite a felicitous choice), perhaps from a more general awareness of what needed to be imported from other cultures or, better, of what Romania needed to fill the gap created by the 42-year communist rule. Translation was part of both his 'program' and of his sparkling personality while his agency was manifest in all he did, including creating communities. His only four translations of Dylan are widely known in Romania, and not only among the Pasărea colibri fans. However, one of his radio co-workers recounts that he did not believe in ratings and offers on her website his exact words: "I need to tell you something about this stupid thing called ratings. Back in the day, Jesus's rating was lower than Barabas's. 
And the people chose Barabas. I wonder if that was OK." (Isopescu 2013, web) Although he didn't believe in ratings, he managed to create covers of Dylan's music that most Romanians passionate about music are familiar with.

\section{Conclusion}

These examples related to rock lyrics translation show that Romanian rock music scene was a complex phenomenon that presented multiple ways of translation deployment, all indebted to a network of music enthusiasts rather than to any cultural politics. First, post-Communist rock music was heavily influenced by the European and American countercultures, but still retained its own modes of expression, which revolved more consistently around presenting alternatives to mass-produced culture, and mostly lacked the dissident emphasis that characterized similar movements. Instead, Romanian underground culture gravitated around archaic ritualism, folklore, and mysticism (including shamanism and traditional magical practices), an attempt at embracing Romania's pre-communist past. Second, the celebration of rock music via lyrics translation is also represented by a more popular form, that of cover versions. Covers were the sole initiative of the artists, who chose either to observe the original poem and provide an accurate translation (like Pittiș), or to adapt the original lyrics, offering an accurate rendition of the titles but largely modifying the main portion of the poem (like Andrieș) in order to preserve the performative aspect. Covers are either only performed, or are doubled by isolated publishing initiatives (e.g., Andries, published the anniversary volume of adaptations dedicated to Dylan, but never published a similar work again). Third, also in line with the celebratory function of translation, there are translation initiatives that stem from the publishers' affinity with a certain artist. The extent of the initiative relies on the financial power of the publisher, and the degree of faithfulness to the original depends on the translator's profile. Fourth, and most importantly, all rock lyric translation in Romania has been built on individual taste and the promotion of such work depended largely on 
a tightly knit network of music enthusiasts who found ways to reach wider audiences.

\section{References}

BIRO, Zoltan and ROSTAS, Zoltan. Images of Europe in Romania: The EU Discourse. Social Science in Eastern Europe (TAMAS, P. and BECKER, U., Eds.). Berlin: GESIS, p 92-102, 2001.

BISHOP, Claire. Artificial Hells. Participatory Art and the Politics of Spectatorship. London; New York: Verso Books, 2012.

DOBRESCU, Caius. The Phoenix That Could not Rise. Rock Culture in Romania, 1960-1989. East Central Europe, v. 38, n. 2-3, p. 255-290, 2012.

DWYER, Tessa and URICARIU, Ioana. Slashings and Subtitles: Romanian Media Piracy, Censorship, and Translation. A Reader on International Media Piracy: Pirate Essays (BAUMGÄRTEL, T., Ed.). Amsterdam: University of Amsterdam Press, 2015.

DYLAN, Bob. (La mulți ani) Dylan (Trans. Alexandru Andrieș). Brașov: Editura Pronto, 1991.

FICHTER, Madigan. Rock ' $n$ ' Roll Nation: Counterculture and Dissent in Romania, 1965-1975. Nationalities Papers v. 39, n. 4, p. 567-585, 2011.

GEZARI, Janet and HARTMAN, Charles. Dylan's Covers. Southwest Review v. 95, n. 1-2, p. 152-166, 2010.

IONESCU, Doru. Timpul chitarelor electrice: Jurnal de calatorie în arhiva TVR (vol. 1). Bucharest: Humanitas Educational, 2005.

IONSCU, Doru. A fost odată (V). Actualitatea muzicală n. 5, web: http://bit.ly/2CYE4yq, 2001.

ISOPESCU, Maria. Buricul pământului, mariaisopescu.ro, Web. http://bit.ly/navelpittis, 2013.

KERIM, Silvia. Cea mai mare bucurie? Faptul că trăiesc clipa de față. Formula As n. 782, web: http://bit.ly/kerimpittis, 1999. 
LUCA, Ioana. Postcommunist American Dreams in Romanian Music. The Transnationalism of American Culture: Literature, Film, and Music (Davis, R.G., Ed.). New York: Routledge, 2013.

McMICHAEL, Polly. Translation, Authorship, and Authenticity in Soviet Rock Songwriting. The Translator v. 14, n. 2, p. 201-228, 2003.

MOCEANU, Radu. Portret: Florian Pittiș, un spirit tânăr și liber, care a onorat radioul. Rador.ro, web: http://bit.ly/motupittis, 2017.

NEGUS, Keith. Popular Music and Social Reality. International Association for the Study of Popular Music. 6th International Conference. Humboldt University, Berlin, July 15th-20th 1991. Popular Music v. 11, n. 1, p. 107-109, 1997.

OIȘTEANU, Andrei. Mircea Eliade și mișcarea hippie. Dilema veche n. 120, web: http://bit.ly/2D07714, 2006.

POP, Doru. Pop-Rock and Propaganda during the Ceaușescu Regime in Communist Romania. Pop Music, Culture and Identity. Breaking the Cold War Paradigm (MAZIERSKA, E., Ed.) London: Palgrave MacMillan, 2016.

STOICESCU, Bogdan Lucian. In memoriam Florian Pittiş (1943 - 2007). Cuvinte, sunete, Imagini, web: http://bit.ly/2BzbTHX, 2009.

TISMĂNEANU, Vladimir. In Memoriam Cornel Chiriac: Un neuitat soldat al libertăţii. Contributors.ro, web: http://bit.ly/2Ed6vYC. May 10, 2012.

VASILIU, Alex. Un model, după 30 de ani. Ziarul de Iași, web: http://bit.ly/2m0CdBa, April 7, 2005.

\begin{abstract}
In this essay I examine rock lyric translations and how the network effect of radio and theater increases the popularity of indie translations compared to versions of the same text circulating via traditional book distribution channels. Using the particular example of Romania before the fall of Communism, I argue that in such 'spaces' translation should not be analysed in terms of social networks of influence only, but also as information networks fuelled by users
\end{abstract}


through free labor, out of personal interest, and via manifold creative processes.

Keywords: Rock, Lyric translations; Network effect; Romania; Communism.

\section{Resumo}

Neste ensaio, examino as traduções de letras de rock e como o efeito de difusão do rádio e do teatro aumenta a popularidade dessas traduções, se comparadas às versões dos mesmos textos que circulam nos canais tradicionais de distribuição de livros. Com base no exemplo particular da Romênia antes da queda do comunismo, defendo que, nesses "espaços", a tradução deve ser analisada não apenas como difusão social de influência, mas também como difusão de informação alimentada pelos usuários por meio de trabalho livre, por interesse pessoal e através de vários processos criativos.

Palavras-chave: Rock; Traduções de letras; Efeito de difusão; Romênia; Comunismo. 